\title{
Word and line bisection in typical and impaired readers and a cross-language comparison
}

\author{
Yafit Gabay ${ }^{1,4}$, Shai Gabay ${ }^{1,2}$, Avishai Henik ${ }^{3}$, \\ Rachel Schiff ${ }^{4}$ and Marlene Behrmann ${ }^{1}$ \\ 1Department of Psychology, Carnegie Mellon University, Pittsburgh PA USA \\ ${ }^{2}$ Department of Psychology and the Institute of Information Processing and Decision Making, \\ University of Haifa, Israel \\ ${ }^{3}$ Department of Psychology and Zlotowski Center for Neuroscience, Ben-Gurion University of the \\ Negev, Beer-Sheva, Israel \\ ${ }^{4}$ School of Education and Haddad Center for Research in Dyslexia and Learning Disabilities, \\ Bar-Ilan University, Ramat-Gan, Israel
}

Number words: 6599

Number tables: 4

Number figures: 4

All correspondence should be directed to Yafit Gabay, Ph.D., Edmond J. Safra Brain Research Center for the Study of Learning Disabilities, Department of Learning Disabilities; Department of Communication Sciences and Disorders; University of Haifa; Mount Carmel, Haifa, Israel 31905. Email: yafitvha@gmail.com

Acknowledgements: This research was supported by grants to $\mathrm{MB}$ from the National Science Foundation \#SBE-0542013 (Garrison W. Cottrell, PI) and \#BCS-1354350 (Marlene Behrmann, PI). 


\begin{abstract}
Observers exhibit larger leftward bias when bisecting words compared with lines. According to the Attentional Scaling Hypothesis, attempting to access lexical entries involves focusing attention on the initial letters of words to establish a cohort of potential matches with entries in the mental lexicon. We test this account by examining two predictions: (1) greater leftward bias for words should be evident in English readers in which the word beginning is on the left but not in Hebrew readers (2) Dyslexics who have lexical impairments should show greater bias. Results reveal that word length modulated bisection bias differently for Hebrew and English readers, although the bias stays always leftward. Furthermore, dyslexics exhibited an exaggerated leftward bias than controls. We propose this effect arises from an interaction between reading and spatial attention rather than from the scaling of attention relative to the beginning of the word in the service of lexical access.

Keywords: Bisection, hemi-spatial attention, lexical processing, reading direction, word representation.
\end{abstract}




\section{Introduction}

When participants are required to bisect a line, they typically do so slightly to the left of the true center, demonstrating what has come to be termed 'pseudoneglect' (Bowers \& Heilman, 1980). Pseudoneglect is thought to reflect stronger activation of the right hemisphere (RH) than the left hemisphere $(\mathrm{LH})$ in response to the visuospatial nature of the line bisection task (Bowers \& Heilman, 1980; Kinsbourne, 1970). Interestingly, there are several factors that can modulate line bisection such as the hand used for the bisection (Jewell \& McCourt, 2000), the manner of bisection such as paper and pencil versus computerized tests (Dellatolas, Vanluchene, \& Coutin, 1996) as well as reading direction (Chokron \& Imbert, 1993; Fagard \& Dahmen, 2003; Gabay, Gabay, Schiff, Ashkenazi, \& Henik, 2013). Several studies have demonstrated that participants also exhibit a leftward bias while bisecting words but, interestingly, this leftward bias is even greater in magnitude than the leftward line-bisection bias (Arduino, Previtali, \& Girelli, 2010; Fischer, 1996, 2000a, 2000b, 2004). This enhanced leftward bias for word bisection is replicable across a host of conditions and has been documented in the context of both paper and pencil bisection tasks as well as in a computerized version of the bisection task. Furthermore, the enhanced leftward bias is evident across different word classes (nouns, adjectives and verbs) and across different languages such as German and English (Fischer, 2000a). Finally, this bias emerges regardless of the font type or the font size in which the words are presented (Fischer, 2004), and is independent of the requirement to read the stimulus aloud (Fischer, 2000a).

\subsection{Support for an Attentional Account of the leftward word-bisection bias}

To account for the robustness and widespread manifestation of the leftward bias on word-bisection results as well as the disproportionate bias relative to line bisection, Fischer (1996) proposed the Attentional Scaling Hypothesis. On this account, the leftward bias in word-bisection 
reflects the participant's attempts to access the mental lexicon. Lexical access is often conceived as starting from the beginning of the word and progressing toward its end (Marslen-Wilson, 1987). Thus, the attempts to access the lexical item may involve increased attentional focusing on the initial letters of a word to establish a cohort of potential matches with entries in the mental lexicon. Consistent with this idea, the analysis of eye movements during reading reveals that readers fixate on a location to the left of true center when first looking at a new word and also tend to shift fixations further to the left of the midpoint as word length increases (O'Regan, 1990; Rayner, 1979). The critical role of word initial letters is well established, and the initials letters are recognized even when the word beginning is presented parafoveally (White, Johnson, Liversedge, \& Rayner, 2008). The unintended consequence of this hypothesized attentional strategy for lexical access is that there is over-representation of the initial part of the word relative to its actual physical extent, and this results in systematic leftward bias when bisecting words (Fischer, 2004).

Considerable empirical evidence from bisection studies is also compatible with this Attentional Scaling Hypothesis. First, the misperception of the word center is reported for different types of orthographic stimuli (words, pseudowords, and symbol strings), but not for nonalphabetic stimuli such as bars, dashes, or boxes (Fischer, 2000b). Also, the enhanced leftward bias is abolished for letter string bisection, indicating that, in the absence of lexical and phonological information, there is no leftward scaling (Fischer, 1996; Exp. 5). Second, bisection errors tend to increase with the length of the stimuli (Arduino et al., 2010; Fischer, 2004) although, of note, it is the number of characters in a word and not the physical extent of the stimuli that determines the size of the error (Fischer (2000b). This perceptual length sensitivity occurs for bisection of orthographic stimuli but not for bisection of lines indicating that the former undergoes additional processing. This is consistent with the idea that it is higher cognitive processes (lexical access) rather than physical properties of the stimulus per se that determine 
performance in bisection. Third, the word bisection bias differs as a function of one's linguistic skill: for example, bisection differs when the bisection task is performed on words in one's second language, compared with words from one's native tongue. That is, when Hebrew-American bilinguals bisected words in their second language (i.e. bisected English words) they revealed a stronger leftward bias (perhaps indicating increased difficulty in lexical access) compared with native readers (Fischer, 1996; Exp. 6). This result is compatible with the claim that extent of lexical access affects the strength of the bias.

Finally, the enhanced leftward bisection for words appears to be strongly dependent on the structure of the orthographic input. For example, Lee et al. (2004) asked both healthy and neurologically impaired participants to bisect either long strings of letters from the Korean alphabet (letter-line bisection), nonlinguistic symbols (star line bisection) or solid lines. Specifically for both the letter and star line bisection tasks, participants were first instructed which character to find, then to identify an exemplar of the target letter, and, thereafter, to determine the midpoint of the linear array. Under these conditions, in the absence of real words, a rightward bias was observed for letter and star lines compared with solid lines. This same result was replicated in a further study conducted on both younger and older healthy participants (Lee et al., 2004) (for related results, see Mohr \& Leonards, 2007). These authors suggested that the stronger rightward bias observed for letter lines may arise from left hemisphere activation due to 1) verbal information associated with individual letters and 2) local attention to letters as compared to global attention to lines.

As evident from the brief review above, there are at least two conflicting accounts having to do with spatial bias in line and word bisection. According to the hemispheric activation account (Bowers \& Heilman, 1980; Kinsbourne, 1970), the leftward attentional bias observed during 
bisection tasks (pseudoneglect) arises from a stronger activation of the right than left hemisphere in response to the visuospatial aspects of the task. Accordingly, people who suffer from left-sided neglect exhibit a rightward bias as the intact left hemisphere shifts attention toward the contralateral, right hemispace (Reuter-Lorenz, Kinsbourne, \& Moscovitch, 1990). By extension, this account would explain the leftward bias for bisecting words in the same way - it is the spatial pattern rather than the content per se that shifts the center to the left. This account, however, does not articulate an obvious mechanism for explaining the greater leftward bias for words over lines and thus, does not fully account for the data. The Attentional Scaling hypothesis, on the other hand, specifically addresses this word/line discrepancy and suggests that the enhanced word bisection bias reflects the participant's attempts to access the mental lexicon and the increased attentional activation associated with this process. The unintended consequence of this hypothesized attentional strategy for lexical access is that there is over-representation of the initial part of the word relative to its actual physical extent, resulting in systematic leftward bias when bisecting words (Fischer, 2004).

\subsection{The current study}

Here, we test several predictions of the Attentional Scaling Hypothesis. The first prediction is that, if the leftward bias for words arises as a result of lexical activation for the informative beginning of words, the leftward bias should only be evident for readers of languages where the word beginning is on the left (as in English) but not for readers of languages where the word beginning is on the right (Hebrew readers). To evaluate this, we compared the bisection performance of native Hebrew and English speakers on lines and words in their native orthography. If the Attentional Scaling Hypothesis holds, we would expect to see greater leftward bias for words than lines in English readers but greater rightward bias for words than lines in 
Hebrew readers. As an intermediate condition, we also included pseudowords in each language with the expectation that the bisection bias for these trials should be in the same direction as for words if the source of the bias is lexical albeit not as large. The second prediction concerns the impact of lexical access on the leftward word bisection bias; specifically, the Attentional Scaling Hypothesis predicts that individuals who have difficulties in lexical access and reading, such as those with Developmental Dyslexia (DD), might reveal even greater word bisection bias than in controls reflecting the additional effort required to activate lexical representations.

Third, the Attentional Scaling Hypothesis predicts that word bisection should be affected by the frequency of occurrence of the word. High frequency words are accessed faster than low frequency words (Morton, 1969) and are fixated for a shorter time in reading compared with low frequency words (Rayner, 1977). Thus, the Attentional Scaling Hypothesis would predict greater leftward bias when lexical access is more demanding as in the case of low frequency words (Raney \& Rayner, 1995). Moreover, this pattern might potentially be disproportionately exaggerated in DD readers, in whom lexical access is disrupted and greater effort is required to activate lexical representations, relative to typical readers.

\section{Bisection performance in developmental dyslexia}

Thus far, the focus has been on lexical access as key in provoking the leftward bias for word bisection in both normal readers and DD readers. It is the case, however, that DD might not only be a consequence of difficulties in lexical access (largely resulting from problems in phonological processing) but might also reflect difficulties in spatial attention. As such, alterations in line bisection in these individuals might result from one or more than one underlying mechanisms. 
The evidence for spatial attention problems in DD comes largely from the Magnocellular Theory, which asserts that the magnocellular pathway is selectively disrupted in individuals with DD, leading to visual/auditory perceptual deficits as well as difficulties in visuospatial attention via the posterior parietal cortex (Vidyasagar \& Pammer, 2010). The causal link between spatial attention and reading abilities has been demonstrated by a longitudinal study (Franceschini, Gori, Ruffino, Pedrolli, \& Facoetti, 2012) and by a remediation study in which action video games have been found to improve reading among dyslexics by improving individuals' attentional abilities (Franceschini et al., 2013). Additional evidence for the link among attention, the magnocellulardorsal pathway and reading has been demonstrated also by others (Gori \& Facoetti, 2014, 2015; Gori et al., 2015; Vidyasagar, 2013). Indeed, studies using line bisection with DD individuals have been conducted to assess the spatial bias but the findings from these studies are inconsistent. Whereas one study demonstrated an exaggerated rightward bias during line bisection tasks among DD participants, a pattern that was attributed to under functioning of the right hemisphere (Sireteanu, Goertz, Bachert, \& Wandert, 2005), other studies have reported a slight leftward bias under similar conditions (Gabay et al., 2013; Polikoff, Evans, \& Legg, 1995). No study has examined word bisection in DD and we do so here.

\section{Experiment 1}

In this first study, we start by comparing the word- and line-bisection bias in typical English and Hebrew readers. 


\subsection{Method}

\subsubsection{Participants}

Two groups of normal readers were included, one comprising 15 native English readers and the other 15 native Hebrew readers. The study was approved by the Institutional Review Board at Carnegie Mellon University and by the ethics committee of the Ben-Gurion University of the Negev. Participants were paid for their participation or received course credit. All participants had normal or corrected-to-normal visual acuity. The English readers ( $8 \mathrm{M}, 7 \mathrm{~F})$, were right-handed university students in Pittsburgh and all provided written informed consent. No participant selfreported signs of sensory or neurological deficits nor learning disabilities on questioning. The Hebrew readers were fifteen right-handed university students $(9 M, 6 F)$ and all gave written informed consent. All participants were native Hebrew speakers and none reported signs of sensory or neurological deficits or learning disabilities. The mean age of the readers was 20.8, S.D. $=2.67$ for the English group and 23.73, S.D. $=2.08$ for the Hebrew group.

\subsection{Stimuli}

A set of 40 words previously used by Gilhooly and Logie (1980), selected based on frequency comprised the English word stimuli (on a scale ranging from 1-7; 1=low frequency, 7=high frequency). Half the words were of high frequency, average $=6.13$, while the other half was low frequency, average=4.15). Word length was orthogonally crossed with frequency, with half the words being relatively short (5-6 characters) and the remaining half longer (7-8 characters). Pseudowords were created by changing 1-2 letters of each of the English words and in most cases, 2 letters were changed (e.g. exterior-axteriol). Pseudowords and words were matched for number of letters, syllables and orthographic structure. Finally, 40 lines were generated matching each 
individual word and pseudo word for length (e.g., mother). Thus, there was a matched triplet of a word, pseudo word and line, all sharing the same length.

A set of 40 Hebrew words was taken from Henik, Rubinstein, and Anaki (2005). Note that the norms in Henik et al. (2005) were developed to parallel those of Gilhooly and Logie (1980) and thus, the frequency for both the English and the Hebrew words had the same scale for word frequency (1=low frequency, $7=$ high frequency). Word length was orthogonally crossed with frequency, with half the words being relatively short (5-6 characters) and the remaining half longer (7-8 characters). As was true for the English stimuli, the Hebrew words were selected by frequency, with half of the set being high- and the other half low in frequency. Pseudowords were created by changing 1-2 letters from the set of words with most of the words having 2 letters changed (e.g-פירמידה-תיפמידה). Finally, 40 lines were generated matching each single word and pseudo word for length (e.g., מקולקל). As with the English words, there was a triplet consisting of a word, its derived pseudoword and a line, all of which were of equal length.

\subsubsection{Task and Procedure}

We followed the procedure by Arduino et al. (2010). Participants were individually tested in a quiet, dark room. They sat approximately $55 \mathrm{~cm}$ from a computer screen. Each trial began with the presentation of a stimulus followed, after $300 \mathrm{~ms}$, by the appearance of the mouse cursor. The mouse cursor was a vertical rectangle $0.9^{\circ}$ (visual angel) high and $0.5^{\circ}$ wide. It appeared along the central axis of the screen at a fixed distance of $0.3^{\circ}$ under the stimulus, and it moved only horizontally. Each stimulus appeared at a randomly chosen screen location, with the limitation that there were at least 50 pixels between each side of the stimulus and the monitor frame. In particular, for each stimulus category, the stimuli appeared with the same frequency in

the four quadrants (upper-left, bottom-left, upper-right, bottom-right) of the screen in a random 
location within each quadrant. The pseudorandom order of the stimuli positions was different for each subject. Letters were presented in uppercase using 45-point Lucida Console font. All stimuli were shown in black font on a white background. The task required participants to estimate the midpoint of each stimulus by positioning the cursor underneath the stimulus and pressing the mouse button. Response accuracy was recorded to the nearest pixel and the latency between presentation of the stimulus and response production was also logged. The stimulus disappeared after $3 \mathrm{~s}$ and the inter-trial interval was $1000 \mathrm{~ms}$. Trials that were timed-out were repeated later in the block.

\subsubsection{Results}

Bisection performance was calculated by subtracting the distance between the cursor position and the objective center of the stimulus with errors to the left of the midpoint given a negative value and errors to the right given a positive value. Similar to Arduino et al. (2010), bisection judgments that exceeded \pm 2.5 SD from the mean bias for each length were considered random errors and excluded from the analysis. Similarly, response latencies beyond 2.5 SD from the mean were considered lapses of attention and excluded from further analyses. Average bisection performance was determined in pixels for each subject and submitted to multiple analyses. As evident below, we first compared bisection distance for words, pseudowords and lines as a function of reader group (English, Hebrew). Then, we tested bisection performance for each stimulus type against zero. Following that, we examined the contribution of word frequency to word bisection performance for both readers groups (frequency is not crossed with stimulus condition (neither pseudowords nor lines are subject to this manipulation) and so this secondary analysis includes only words) 
ANOVA was conducted on the accuracy of bisection performance with group (English vs. Hebrew readers) as a between-subjects factor and stimulus type (words, pseudowords, and lines) and length (short vs. long) as within-subject factors. The results are presented in Figure 1. The main effect of group was not significant $F<1$ indicating that the bisection bias was equivalent for the two groups of readers. There was a significant main effect of stimulus type, $[F(2,56)=10.33$, $p<.05]$; further analysis revealed that words elicited significantly larger leftward biases compared with lines, $[F(1,28)=16.103, p<.05]$, and that words elicited a marginally significant larger leftward bias compared with pseudowords, $[F(1,28)=3.44,, p=.07]$. Pseudowords elicited a significantly larger leftward bias compared with lines, $[F(1,28)=7.49, p<.05]$. The length by group interaction was significant, $[F(1,28)=32.07, p<.05]$ as was the three-way interaction of stimulus type $\mathrm{x}$ length $\mathrm{x}$ group, $[F(2,50)=10.44, p<.05]$. Further analysis revealed that longer words were bisected further to the left compared with shorter words for English readers (thus replicating previous findings, Fischer, 2004), while the opposite pattern was observed for Hebrew readers, $[F(1,28)=18.75, p<.05]$ although the direction of the bias always stayed left. A similar pattern was observed for pseudowords, $[F(1,28)=28.01 p<.05]$, and length did not modulate bisection of lines for either the English or Hebrew readers. $[F<1]$.

The average bisection performance was -1.33 pixels $(S D=2.17)$ for words, -0.78 $(S D=2.53)$ for pseudowords and $0.56(S D=2.92)$ for lines. Performance differed significantly from accurate bisection for words i.e. absolute midpoint of $0, t(29)=-3.36, p<.05$, but not for pseudowords, $t(29)=-1.73, p=.09$, and not at all for lines, $t(29)=1.06, p=.29$. Note that, although the magnitude of the effects appear small, these are roughly of the same magnitude as previous findings (Arduino et al., 2010). 
To explore the effect of word frequency on word bisection performance, we conducted an ANOVA using accuracy of bisection as the dependent measure with Group (English vs Hebrew readers) as a between-subjects factor and word Frequency (high, low) as well as length (short vs. long words) as a within-subjects factors. The results are presented in Figure 2. The main effect of group was not significant $[F<1]$. The main effect of length was marginally significant, $[F(1$, $28)=3.26, p=.08]$. The main effect of Frequency was significant, $[F(1,28)=5.02, p<.05]$, with low frequency words eliciting larger leftward bias $(M=-1.58$, S.D. $=0.41]$ compared with high frequency words $[M=-1.08, S . D .=0.409]$. The group by frequency interaction was not significant, $[F(1,28)=$ $1.88, p=.181]$. The length $x$ group interaction was significant, $(F(1,28)=18.75 p<.05)$ : for Hebrew readers, short words elicited larger leftward bias compared with long words, $(F(1,28)=3.31, p=.08)$ but, for English readers, the opposite pattern was observed with long words elicited significant larger leftward bias compared with short words, $(F(1,28)=18.82, p<.05)$. There was also a significant interaction of length $x$ frequency, $(F(1,28)=17.63, p<.05)$ which emerges from the fact that bisection performance of high frequency words was not modulated by length $[F<1]$. However, bisection of low frequency words was modulated by length with the long low frequency words eliciting greater leftward bias compared with short low frequency words, $(F(1,28)=14.48, p<.05)$. The three-way interaction was significant, $F(1,28)=4.23, p<.05$; further analysis revealed that, for long words, the two groups of readers behaved similarly, $F<1$, with long low frequency words eliciting a larger leftward bias compared with long high frequency words. For short words, an opposite pattern was observed for English readers, $F(1,28)=10.63, p<.05$, whereas for Hebrew speakers', frequency did not modulate the bisection of short words, $F<1$. 


\subsubsection{Discussion}

The current experiment compared native English and Hebrew readers on the bisection of words, pseudowords and lines. Overall, the two groups of readers exhibited a leftward bias of similar magnitude when bisecting orthographic stimuli compared with solid lines, and also showed a greater leftward bias for words than for pseudowords. Moreover, there was an effect of word frequency on bisection with both groups of readers evincing a larger leftward bias for low than for high frequency words. Last, although the direction of the bias was always leftward, word length modulated bisection bias differently for Hebrew and English readers. Specifically, for typical English readers, long words were bisected further to the left compared with short words (thus replicating previous findings, Fischer, 2004) while the magnitude of the leftward bias was greater for short than for long words for the Hebrew readers. A similar pattern was observed for pseudowords. This suggest that, although there is a robust leftward bisection bias in both groups of readers, there is some influence on bisection performance that is related to the direction in which reading proceeds such that for longer words, the bias is exaggerated toward the beginning of the word (left in English, right in Hebrew). Taken together, these results challenge the Attentional Scaling Hypothesis because both Hebrew and English readers demonstrated a significant leftward bias during word bisection. There is, indeed, an influence of word frequency on bisection magnitude and bisection bias is greater for words than for lines or for pseudowords, suggesting that lexical access is implicated in bisection but, importantly, the direction of the bias holds for the two scripts, independent of reading direction. There is some influence of reading direction as the location of the initial letters does modulate the bisection magnitude with a slight pull of the bias to the location of the initial letters of the word for longer compared with shorter words. Together, these results suggest that the existing version of the 
Attentional Scaling hypothesis cannot account for these findings, and we offer an alternative explanation in the General Discussion.

\section{Experiment 2}

The results of Experiment 1 challenge the current version of the Attentional Scaling Hypothesis. In this next experiment, we test a further prediction of this account: if the word bisection bias results from attempts to access lexical representations, then we should expect to observe greater bias relative to controls when lexical processing is more difficult as in individuals who have developmental dyslexia (DD) (Milne, Nicholson, \& Corballis, 2003). Here, we examine the word bisection bias in individuals who are native Hebrew readers but who have DD. Given that the typical Hebrew readers show a leftward word bisection bias (equivalent to the English readers as above), we might also expect to see a leftward bias in these DD individuals and we expect that this should be exaggerated relative to the typical readers. We also predict an exaggerated effect of word frequency on bisection in the DD readers reflecting the further burden of activating low frequency lexical representations.

\subsection{Methods}

3.1.1 Participants. Thirty university/college students, all native Hebrew readers, participated in this experiment: a group of individuals with DD (9M, 6F) and a matched control group (9M, 6F). Mean age was 26.2, S.D. $=2.39$ for the DD group and 23.73, S.D. $=2.08$ for the control group. The fifteen controls were the Hebrew reading participants from Experiment 1 who returned to the lab in order to complete an additional cognitive battery of tests. All participants were right-handed. Individuals with DD were recruited by advertisements placed in centers for individuals with learning disabilities. Students were either paid 30 NIS ( $\$ 7.5)$ for participation in the experiment or received course credit. The study was approved by the ethics committee of the Ben-Gurion University of the Negev, and written informed consent was 
obtained from participants. All participants were native Hebrew speakers with no reported signs of sensory or neurological deficits/attention deficit hyperactive disorder (according to the American Psychiatric Association, 2000) and all came from middle to high socioeconomic status families. Participants with DD had a well-documented history of DD and were diagnosed as having DD during childhood. They reported substantial difficulties in acquiring reading and writing skills at school. At the time of their participation in this study, these individuals were identified as having DD by the learning disabilities centers in their institutions and had received special accommodations.

All participants completed a series of cognitive tests in order to evaluate their general intelligence (as measured by the Raven Progressive Matrices), reading abilities (Schiff \& Kahta, 2009a, 2009b), verbal working memory (as measured by the Digit Span from the Wechsler Adult Intelligence Scale (Wechsler, 1997) and rapid naming (Shany, Lachman, Shalem, Bahat, \& Zeiger, 2006). The two groups did not differ on the basis of intelligence or age, but, as expected, the DD group performed more poorly than the control group on tests of reading measures, processing speed and verbal working memory (see Table 1). The reading achievement of the DD group was significantly below expected performance given age, cognitive ability (all scored above the $50^{\text {th }}$ percentile on the Raven test) and educational opportunities, and all scored below the 50th percentile in word and non-word reading tests on either accuracy and/or speed measures.

\subsubsection{Procedure}

The DD participants completed the task exactly as described in Experiment 1 above (the data for the control participants were taken from Experiment 1). 


\subsubsection{Results}

A repeated measure ANOVA was conducted with group (DD vs. Controls) as a betweensubjects factor and stimulus type (words, pseudowords, and lines) as a within-subjects factor with accuracy of bisection performance as the dependent measure. The results are presented in Figure 3. There was a main effect of group, such that DD Hebrew readers exhibited significantly larger leftward bias compared with the Hebrew reading controls, $[F(1,28)=5.07, p<.05]$. There was also a significant main effect of stimulus type, $[F(2.56)=9.17, p<.05]$. Further analysis revealed that words elicited significantly a larger leftward bias compared with lines, $[F(1,28)=13.14, p<.05]$, but did not differ from pseudowords, $[F(1,28)=1.99,, p=.16]$. Pseudowords elicited significant larger leftward bias compared with lines, $[F(1,28)=8.82, p<.05]$. The interaction of stimulus type by group was not significant, $[F(2,56)=1.06, p=.35]$.

For the control group, the average bisection performance for was -0.94 pixels $(S D=2.67)$ for words, $-0.23(S D=1.78)$ for pseudowords and $0.40(S D=2.52)$ for lines. Performance differed significantly from accurate bisection (zero) for words, $t(14)=-2.15, p<.05$, but not for pseudowords $t(14)=-0.501, p=0.63$, or for lines, $t(14)=0.61, p=.54$. For DD Hebrew speakers, the average bisection bias was -2.43 pixels $(S D=1.83)$ for words, $-2.18(S D=1.78)$ for pseudowords and -0.36 (SD=2.7) for lines. Performance differed significantly from accurate bisection (zero) for words, $t(14)=-5.12, p<.05$ and for pseudowords, $t(14)=-3.97, p<.05$, but not for lines, $t(14)=-$ $0.52, p=.60$.

There was also a main effect of length on bisection magnitude with shorter stimuli eliciting a larger leftward bias compared with long stimuli $[F(1,28)=5.51, p<.05]$. The length by group interaction was significant, $[F(1,28)=10.47, p<.05]$ : whereas for DD group, there was no differential leftward bias as a function of length, for the typical readers a larger leftward bias was 
observed for short stimuli compared with long stimuli (as already described for Experiment 1). The stimulus type by length interaction was also significant such that long words and pseudowords were overall bisected further leftward compared with short words while no modulation of length was observed for lines, $[F(1,28)=6.04, p<.05]$.

To explore the effect of word frequency on word bisection performance, an ANOVA with Group (Control vs. DD) as a between-subject factor and word frequency (high, low) and length (short vs. long) as within subject factors was conducted with bisection magnitude as the dependent measure. The results are presented in Figure 4. As expected given the results above, there was a main effect of Group, $[F(1,28)=5.35, p<.05]$, with the DD readers exhibiting a larger leftward bias compared with control Hebrew readers. The main effect of Frequency was also significant $[F(1,28)=5.07, p<.05]$ with low frequency words eliciting a larger leftward bias compared with high frequency words, (low frequency: $M=-2.03$, S.D.=0.302; high frequency: $M=-$ 1.35 , S.D. $=0.4$ ) but there was no interaction of frequency with group, $F<1$. There was no main effect of length, $F<1$, but the interaction of length by group was significant $(F(1,28)=4.402, p<.05)$. Further analysis revealed that long words elicited greater leftward bias among DD Hebrew readers compared with Hebrew typical readers $[F(1,28)=7.14, p<.05]$, while no group differences were observed for the bisection of short words, $[F(1,28)=1.98, p=0.16]$. No other main effects or interactions were significant.

\subsubsection{Discussion}

The results from the current study suggest that when lexical access is difficult, as in the case of DD, a larger leftward bias in observed. This can be taken as indication for the involvement of lexical processes in word bisection. It should be noted that we did not observe an interaction between group and frequency, that is DD presented a larger leftward bias than controls, yet this 
was not modulated by frequency. This might indicate that the difficulty of DD to access lexical representations is similar for both high and low frequency words and produces an additive bias regardless of frequency type. In contrast, we did observe an interaction between group and length indicating a larger leftward bias for long words in DD compared with controls while no difference was observed for short words. It is possible that, in this group, long words need additional lexical processing compared with short words and thus produce greater leftward bias in DD.

\section{General Discussion}

The present study was designed to examine the mechanisms that support the bisection of visual stimuli. If the stimuli to be bisected engage a visuospatial process that activates the spatial extent of the input, then the right hemisphere should be activated, resulting in a leftward bias, and this bisection bias should be equivalent for all kinds of visual stimuli (words, lines etc.). Our findings, as well as those from many previous studies (Arduino et al., 2010; Fischer, 1996, 2000b, 2004; Veronelli, Vallar, Marinelli, Primativo, \& Arduino, 2014), however, document an exaggerated leftward bias when observers bisect words versus lines, ruling out this pure right hemisphere visuospatial account. A more tractable explanation is offered by the Attentional Scaling Hypothesis, which suggests that the exaggerated bias for words over lines results from the activation of the initial letters of the word and the ensuing lexical access--- it is this activation that drives the leftward bias observed in word bisection. This account predicts that if the initial letters of a word appear on the right (as in some reading systems like Hebrew), then the bisection bias would be to the right for those readers. This account also predicts that, under conditions of increased lexical access demands, as in individual with developmental dyslexia (DD), the leftward bias should be exaggerated further. We first review our results and then present an explanation of the findings. 
In the first experiment, in which participants bisected words, pseudowords and lines, we confirmed the established finding that word bisection results in greater leftward bias compared with lines, in accordance with the tenets of the Attentional Scaling Hypothesis (Fischer, 1996, 2000b, 2004): moreover, bisection was greater for words than for pseudowords and both had greater bisection bias than lines. Dramatically, this held true for both English and Hebrew readers, and to an equivalent extent. The leftward bias was greater for low than for high frequency words and, again, equally so for the two groups of readers. Bisection performance was modulated by length, with some differential modulation of the overall left bias in the Hebrew and English readers. In the second experiment, there was an exaggerated leftward bisection bias for words and pseudowords over lines in the DD group compared with the group of control participants. As with Experiment 1, there was greater magnitude leftward bisection for low than for high frequency words and this held equally across the DD and control groups.

While some of the findings can be accounted for by the Attentional Scaling Hypothesis (Fischer, 1996, 2000b, 2004), others cannot and compel an alternative account. The present results do support some aspects of the lexical activation claim: there is an exaggerated leftward bias for words (and pseudowords) over lines and the bias is greater for low than high frequency words, indicating that as lexical access increases in difficulty, so the magnitude of the bias increases. The Attentional Scaling Hypothesis also accounts for the findings that the adults with DD, who presumably have more difficulty in accessing lexical representations than typical readers, show an exaggerated word bisection bias relative to their controls.

Other aspects of the findings, however, cannot be accommodated by this account. The critical challenge to this account is that the bisection bias was leftward for both English and Hebrew readers even though the initial letters of the words (and the apparent origin of lexical 
access effects) are to the left and right, respectively. The performance of the two groups of readers was similar across all dimensions (words versus other visual stimuli, frequency effects) although there was some modulation of the leftward bias as a function of reading direction. Specifically, for typical English readers long words were bisected further to the left compared with short ones (thus replicating previous findings, Fischer, 2004) while the opposite pattern was observed for typical Hebrew readers, although the direction of the bias always stayed leftward. In the second experiment, we found that length did not modulate dyslexics' bisection performance. Despite the modulation of bisection bias by reading direction, both Hebrew and English readers demonstrated a clear leftward bisection bias, which strengthens the claim that the leftward bias observed in Hebrew readers is not a result of a difference in word length between the groups. Thus, despite the difference in spatial position of the initial letters of the word, Hebrew and English readers exhibited a similar leftward bias when bisecting words and this leftward bias was even exaggerated in Hebrew DD readers.

As evident, the Attentional Scaling Hypothesis can account for some but not all of the findings and although lexical access seems important, the word bisection bias appears to be subject to visuo spatial influences, as well. We, therefore, offer an interactive account that takes into consideration both visuospatial/attentional and reading/language factors as contributing to the bias in word bisection. In light of this, we suggest that the activation of both the right and the left hemispheres contributes to bisection performance. However, the relative contribution of each hemisphere depends on the nature of stimuli to be bisected. In the typical line bisection task, the right hemisphere is more involved in visuospatial processing compared with the left hemisphere, resulting in a slight leftward bias. This involvement of the right hemisphere is further enhanced during bisection tasks, which contain lexical information. When the bisection task contains lexical information, the left hemisphere is also engaged by virtue of lexical processing associated with 
word. Because of the engagement in lexical processing, the left hemisphere contributes less to visuospatial processing, thus leading to a greater involvement of the right hemisphere in visuospatial processing of the stimuli. As a result, the visuospatial representation of the stimulus is more pronounced in the right hemisphere compared with the left hemisphere, leading to an enhanced leftward bias. This leftward bias is even further exaggerated when the left hemisphere is engaged in activating low frequency words or when lexical processing is more demanding such as in the case of DD. Lexical access involves left hemisphere and as lexical access become difficult (e.g. low frequency words/DD) and greater demands are imposed on the left hemisphere, the asymmetry between the hemispheres shifts further toward the right hemisphere (and greater leftward bias). This should happen equally for both English and Hebrew speakers as is clear from the current results. Although we do not have direct evidence for this exact dynamic interaction, it might be possible to explore it in, for example, dual task experiments where the left or right hemisphere can be differentially engaged in a second task (e.g. digit repetition) and the impact of the hemispheric effects differentially explored.

To the best of our knowledge, this is the first study that compared word bisection performance in two groups that differed in their reading direction and also in individuals with DD. Thus we were able to compare between several contrasting accounts with different predictions about the processes involved in word bisection.

Before concluding, we need to clarify one point and that concerns the perhaps surprising rightward bias we obtained in our line bisection task and this contrasts with other studies that have demonstrated leftward bias when bisecting lines (Bradshaw, Bradshaw, Nathan, Nettleton, \& Wilson, 1986; Bradshaw, Nathan, Nettleton, Wilson, \& Pierson, 1987; Bradshaw, Nettleton, Nathan, \& Wilson, 1985). Because we used relatively short lines compared with previous studies, 
this might result in the well-known cross-over effect when bisecting lines (Jewell \& McCourt, 2000). Also, in a computerized line bisection task very similar to the one used here, a modest rightward bias is usually observed when bisecting lines (Dellatolas et al., 1996).

Another issue that should be clarified is the exaggerated leftward bias observed in the DD group in the current study. A previous study demonstrated an exaggerated rightward bias during a line bisection task among DD participants, a pattern that was attributed to under functioning of the right hemisphere (Sireteanu et al., 2005). We do note, however, that other studies have failed to replicate those findings: for example, Polikoff et al. (1995) reported a slight leftward bias among dyslexics' readers during line bisection task, and Gabay et al. (2013) reported a leftward bias in dyslexics during a line bisection task. Importantly, it is difficult to compare the current results to those of Sireteanu et al. (2005) since line and word bisection involve different cognitive processes. Along similar lines, although it has been suggested that DD may reflect some aspects of left hemispatial neglect caused by a right parietal lobe dysfunction (Buchholz \& Aimola Davies, 2008; Facoetti \& Molteni, 2001; Hari \& Renvall, 2001; Ruffino, Gori, Boccardi, Molteni, \& Facoetti, 2014; Ruffino et al., 2010), some other studies favor an explanation of under functioning of the left hemisphere. For example, dyslexic adults show reduced left, but increased right, hemisphere activation in temporal-parietal regions during phonological processing, a pattern opposite to that observed in normal readers (Shaywitz et al., 1998). More recent reviews of neuroimaging studies have similarly emphasized a reduction or absence of activity in left hemisphere temporo-parietal cortex in dyslexic individuals during language tasks (McCrory, 2004; Temple, 2002).

\section{Conclusion}

Surprisingly, we observed that in both Hebrew and English readers, the leftward deviation in word bisection was exaggerated relative to line and pseudoword bisection and to an equal 
degree across the two reading groups. We also observed an even greater leftward bias for words relative to lines in individuals with reading difficulties (developmental dyslexia) relative to their controls. These findings prompt a reconsideration of the theoretical accounts offered thus far and we have proposed an explanation that takes into account both the visuospatial and linguistic processes engaged during word bisection. Further tests of our interactive account are needed and we suggest possible empirical approaches for future investigations. 


\section{References}

Arduino, L. S., Previtali, P., \& Girelli, L. (2010). The centre is not in the middle: Evidence from line and word bisection. Neuropsychologia, 48(7), 2140-2146.

Association, A. P. (2000). Diagnostic and statistical manual of mental disorders: DSM-IV-TR: American Psychiatric Publishing, Inc.

Bowers, D., \& Heilman, K. M. (1980). Pseudoneglect: Effects of hemispace on a tactile line bisection task. Neuropsychologia, 18(4), 491-498.

Bradshaw, J. L., Bradshaw, J. A., Nathan, G., Nettleton, N. C., \& Wilson, L. E. (1986). Leftwards error in bisecting the gap between two points: stimulus quality and hand effects. Neuropsychologia, 24(6), 849-855.

Bradshaw, J. L., Nathan, G., Nettleton, N. C., Wilson, L., \& Pierson, J. (1987). Why is there a left side underestimation in rod bisection? Neuropsychologia, 25(4), 735-738.

Bradshaw, J. L., Nettleton, N. C., Nathan, G., \& Wilson, L. (1985). Bisecting rods and lines: effects of horizontal and vertical posture on left-side underestimation by normal subjects. Neuropsychologia, 23(3), 421-425.

Buchholz, J., \& Aimola Davies, A. (2008). Adults with dyslexia demonstrate attentional orienting deficits. Dyslexia, 14(4), 247-270.

Chokron, S., \& Imbert, M. (1993). Influence of reading habits on line bisection. Cognitive Brain Research, 1(4), 219-222.

Dellatolas, G., Vanluchene, J., \& Coutin, T. (1996). Visual and motor components in simple line bisection: An investigation in normal adults. Cognitive Brain Research, 4(1), 49-56.

Facoetti, A., \& Molteni, M. (2001). The gradient of visual attention in developmental dyslexia. Neuropsychologia, 39(4), 352-357.

Fagard, J., \& Dahmen, R. (2003). The effects of reading-writing direction on the asymmetry of space perception and directional tendencies: A comparison between French and Tunisian children. Laterality: Asymmetries of Body, Brain and Cognition, 8(1), 39-52.

Fischer, M. H. (1996). Bisection performance indicates spatial word representation. Cognitive Brain Research, 4(3), 163-170.

Fischer, M. H. (2000a). Perceiving spatial attributes of print. Reading as a perceptual process, 89-117.

Fischer, M. H. (2000b). Word centre is misperceived. PERCEPTION-LONDON-, 29(3), 337-354.

Fischer, M. H. (2004). Orthographic contributions to perceived word center. Brain and language, 88(3), 321-330.

Franceschini, S., Gori, S., Ruffino, M., Pedrolli, K., \& Facoetti, A. (2012). A causal link between visual spatial attention and reading acquisition. Current Biology, 22(9), 814-819.

Franceschini, S., Gori, S., Ruffino, M., Viola, S., Molteni, M., \& Facoetti, A. (2013). Action video games make dyslexic children read better. Current Biology, 23(6), 462-466.

Gabay, Y., Gabay, S., Schiff, R., Ashkenazi, S., \& Henik, A. (2013). Visuospatial Attention Deficits in Developmental Dyslexia: Evidence from Visual and Mental Number Line Bisection Tasks. Archives of Clinical Neuropsychology, 28(8), 829-836.

Gilhooly, K. J., \& Logie, R. H. (1980). Age-of-acquisition, imagery, concreteness, familiarity, and ambiguity measures for 1,944 words. Behavior Research Methods \& Instrumentation, 12(4), 395-427.

Gori, S., \& Facoetti, A. (2014). Perceptual learning as a possible new approach for remediation and prevention of developmental dyslexia. Vision research, 99, 78-87.

Gori, S., \& Facoetti, A. (2015). How the visual aspects can be crucial in reading acquisition? The intriguing case of crowding and developmental dyslexia. Journal of vision, 15(1), 8. 
Gori, S., Mascheretti, S., Giora, E., Ronconi, L., Ruffino, M., Quadrelli, E., . . . Marino, C. (2015). The DCDC2 intron 2 deletion impairs illusory motion perception unveiling the selective role of magnocellular-dorsal stream in reading (dis) ability. Cerebral Cortex, 25(6), 1685-1695.

Hari, R., \& Renvall, H. (2001). Impaired processing of rapid stimulus sequences in dyslexia. Trends in cognitive sciences, 5(12), 525-532.

Henik, A., Rubinstein, O., \& Anaki, D. (2005). Word norms for the Hebrew language. Ben Gurion University of the Negev, Beersheba.

Jewell, G., \& McCourt, M. E. (2000). Pseudoneglect: a review and meta-analysis of performance factors in line bisection tasks. Neuropsychologia, 38(1), 93-110.

Kinsbourne, M. (1970). The cerebral basis of lateral asymmetries in attention. Acta psychologica, 33, 193-201.

Lee, B., Kang, S., Park, J., Son, Y., Lee, K., Adair, J., . . Na, D. (2004). The Character-line Bisection Task: a new test for hemispatial neglect. Neuropsychologia, 42(12), 1715-1724.

Lee, B. H., Kim, M., Kang, S. J., Park, K. C., Kim, E.-J., Adair, J. C., \& Na, D. L. (2004). Pseudoneglect in solid-line versus character-line bisection tasks: a test for attention dominance theory. Cognitive and behavioral neurology, 17(3), 174-178.

Marslen-Wilson, W. D. (1987). Functional parallelism in spoken word-recognition. Cognition, 25(1), 71102.

McCrory, E. (2004). The neurocognitive basis of developmental dyslexia.

Milne, R. D., Nicholson, T., \& Corballis, M. C. (2003). Lexical access and phonological decoding in adult dyslexic subtypes. Neuropsychology, 17(3), 362.

Mohr, C., \& Leonards, U. (2007). Rightward bisection errors for letter lines: The role of semantic information. Neuropsychologia, 45(2), 295-304.

Morton, J. (1969). Interaction of information in word recognition. Psychological review, 76(2), 165.

O'Regan, J. K. (1990). Eye movements and reading. Reviews of oculomotor research, 4, 395.

Polikoff, B., Evans, B., \& Legg, C. (1995). Is there a visual deficit in dyslexia resulting from a lesion of the right posterior parietal lobe? Ophthalmic and Physiological Optics, 15(5), 513-517.

Raney, G. E., \& Rayner, K. (1995). Word frequency effects and eye movements during two readings of a text. Canadian Journal of Experimental Psychology/Revue canadienne de psychologie expérimentale, 49(2), 151.

Rayner, K. (1977). Visual attention in reading: Eye movements reflect cognitive processes. Memory \& cognition, 5(4), 443-448.

Rayner, K. (1979). Eye guidance in reading: Fixation locations within words. Perception, 8(1), 21-30.

Reuter-Lorenz, P. A., Kinsbourne, M., \& Moscovitch, M. (1990). Hemispheric control of spatial attention. Brain and cognition, 12(2), 240-266.

Ruffino, M., Gori, S., Boccardi, D., Molteni, M., \& Facoetti, A. (2014). Spatial and temporal attention in developmental dyslexia. Frontiers in human neuroscience, 8.

Ruffino, M., Trussardi, A. N., Gori, S., Finzi, A., Giovagnoli, S., Menghini, D., . . . Vicari, S. (2010). Attentional engagement deficits in dyslexic children. Neuropsychologia, 48(13), 3793-3801.

Schiff, R., \& Kahta, S. (2009a). Non-word reading test. Unpublished manuscript). Haddad Center for Research in Dyslexia, Bar-Ilan University, Ramat-Gan, Israel.

Schiff, R., \& Kahta, S. (2009b). Single-word reading test. Unpublished manuscript). Haddad Center for Research in Dyslexia, Bar-Ilan University, Ramat-Gan, Israel.

Shany, M., Lachman, D., Shalem, Z., Bahat, A., \& Zeiger, T. (2006). Aleph-taph. A test for the diagnosis of reading and writing disabilities, based on national Israeli norms.

Shaywitz, S. E., Shaywitz, B. A., Pugh, K. R., Fulbright, R. K., Constable, R. T., Mencl, W. E., . . Fletcher, J. M. (1998). Functional disruption in the organization of the brain for reading in dyslexia. Proceedings of the National Academy of Sciences, 95(5), 2636-2641. 
Sireteanu, R., Goertz, R., Bachert, I., \& Wandert, T. (2005). Children with developmental dyslexia show a left visual "minineglect". Vision research, 45(25), 3075-3082.

Temple, E. (2002). Brain mechanisms in normal and dyslexic readers. Current opinion in neurobiology, 12(2), 178-183.

Veronelli, L., Vallar, G., Marinelli, C. V., Primativo, S., \& Arduino, L. S. (2014). Line and word bisection in right-brain-damaged patients with left spatial neglect. Experimental brain research, 232(1), 133146.

Vidyasagar, T. R. (2013). Reading into neuronal oscillations in the visual system: implications for developmental dyslexia. Frontiers in human neuroscience, 7.

Vidyasagar, T. R., \& Pammer, K. (2010). Dyslexia: a deficit in visuo-spatial attention, not in phonological processing. Trends in cognitive sciences, 14(2), 57.

Wechsler, D. (1997). WAIS-III: Wechsler adult intelligence scale: Psychological Corporation San Antonio.

White, S. J., Johnson, R. L., Liversedge, S. P., \& Rayner, K. (2008). Eye movements when reading transposed text: the importance of word-beginning letters. Journal of Experimental Psychology: Human perception and performance, 34(5), 1261. 


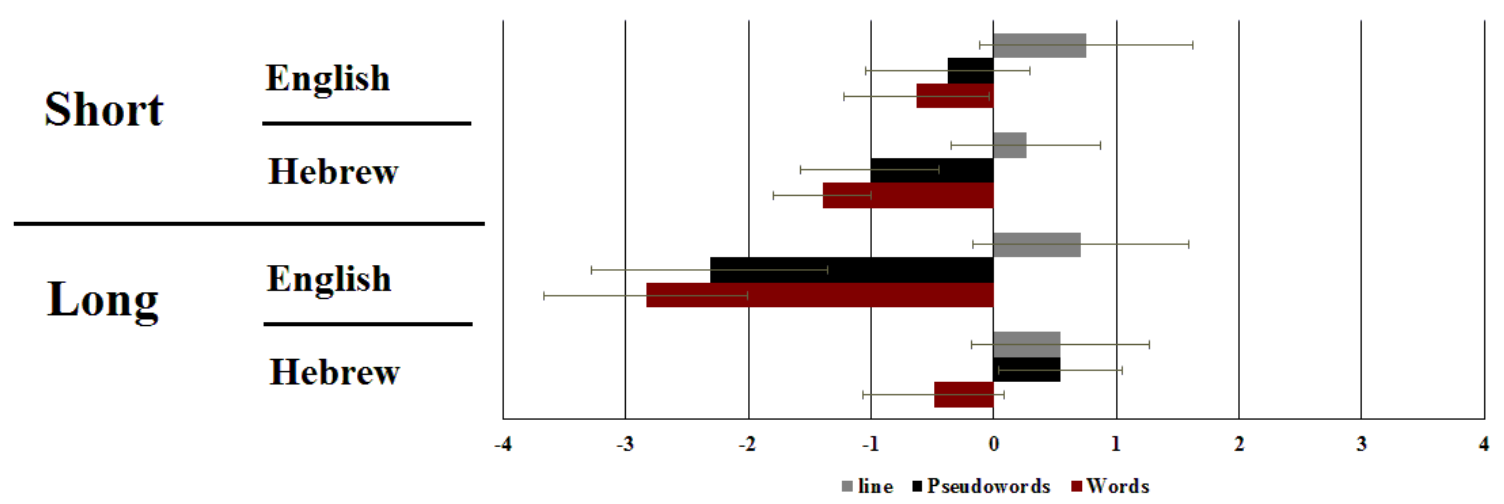

Figure 1: Bisection performance of Hebrew vs. English readers as a function of stimulus type (Words, Pseudo words and Lines) and length (Short vs. Long). Error bars represent standard error. 


\section{English}

Hebrew

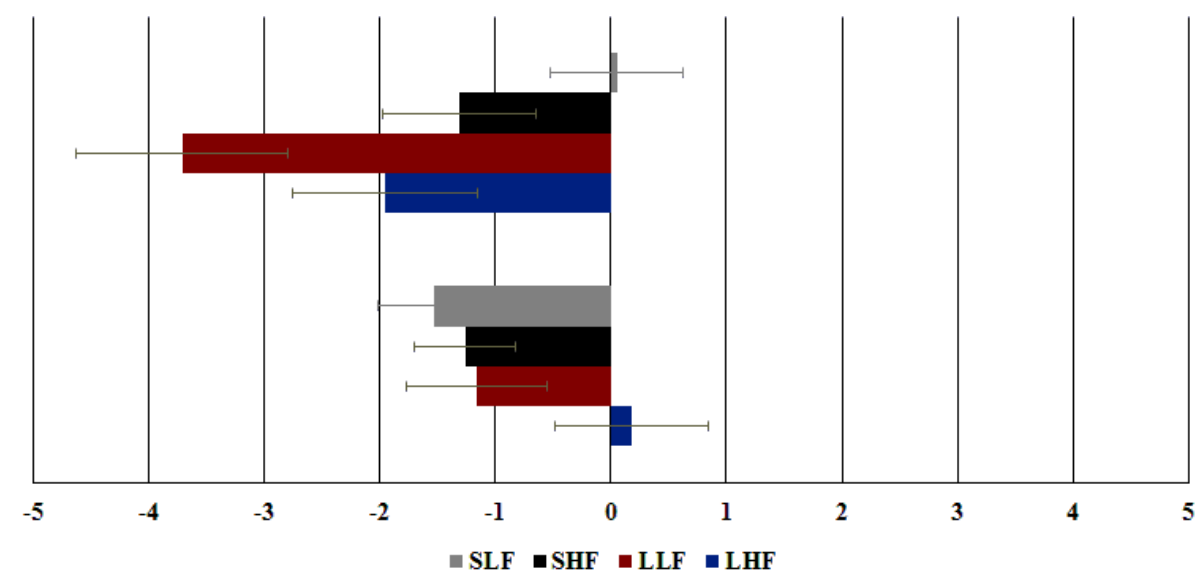

Figure 2: Word bisection performance of Hebrew vs. English readers as a function of frequency (High vs. Low) and length (Short vs. Long). Error bars represent standard error. SLF=short low frequency, SHF=short high frequency, LLF=long low frequency, LHF=long high frequency. 


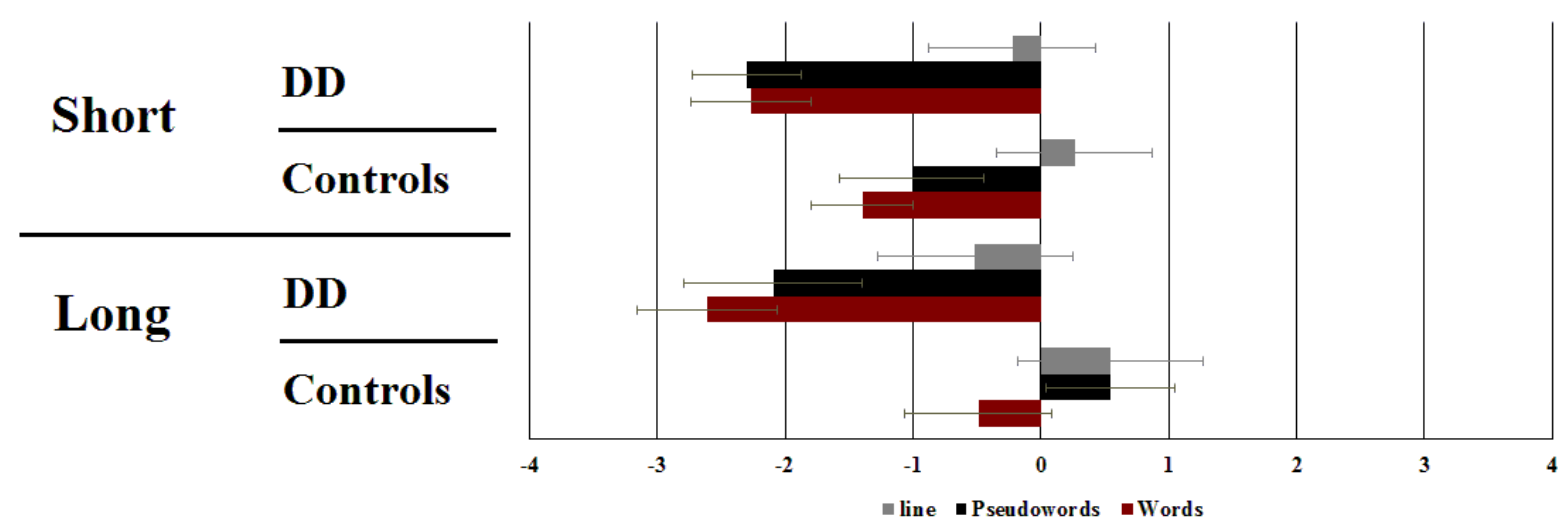

Figure 3: Bisection performance of Hebrew Readers as a function of group (DD vs. Control) stimulus type (Words, Pseudo words and Lines) and length (Short vs. Long). Error bars represent standard error. 


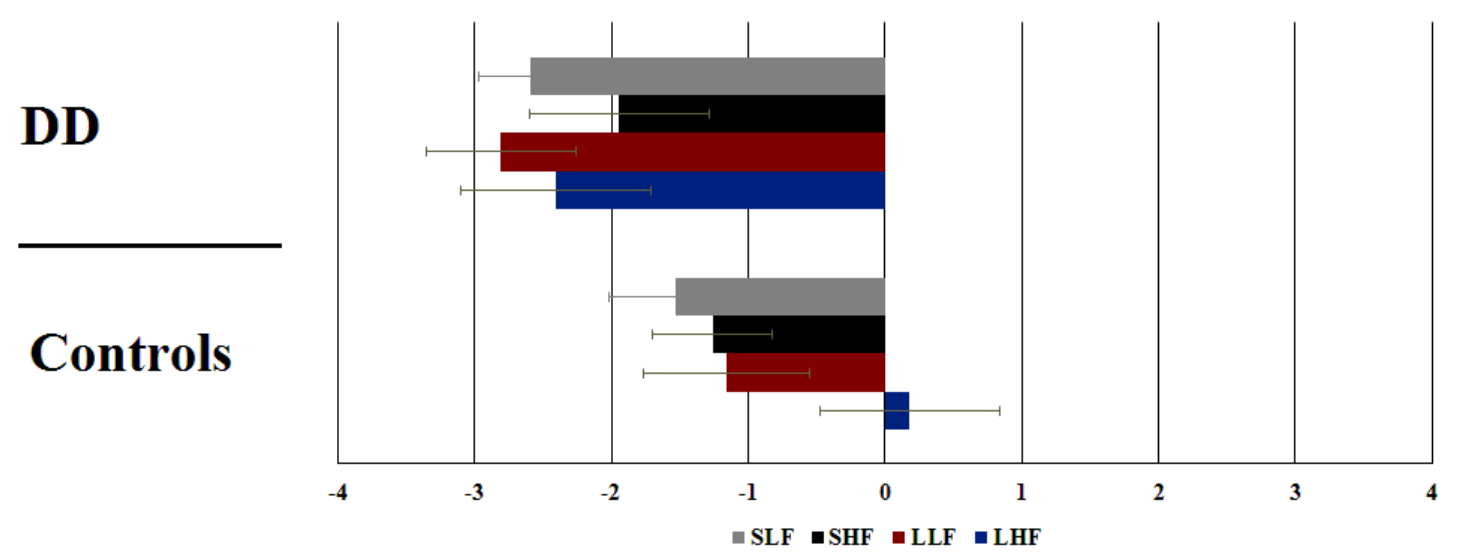

Figure 4: Word bisection performance of Hebrew readers as a function of group (DD vs. Controls) frequency (High vs. Low) and length (Short vs. Long). Error bars represent standard error. 
Table 1 - Demographic and Psychometric data of Hebrew DD and Control groups

\begin{tabular}{|c|c|c|c|}
\hline & Group & & \\
\hline Subtest & Control & DD & $p$ \\
\hline Raven & $57(2.26)$ & $53.66(1.27)$ & n.s. \\
\hline Digit span ${ }^{a}$ & $9.78(2.22)$ & $11.73(2.31)$ & $* *$ \\
\hline Letter naming & $22.73(4.63)$ & 18.33 (2.99) & $* *$ \\
\hline Digit naming & $19.86(3.58)$ & $16.13(3.73)$ & $* *$ \\
\hline RT word reading & $88.6(13.05)$ & $63.8(13.97)$ & $* *$ \\
\hline Acc word reading & $106.66(2.6)$ & $94.2(7.28)$ & $* *$ \\
\hline RT non-word reading & $60.6(18.5)$ & $25(7.52)$ & $* *$ \\
\hline Acc non word reading & $38.93(5.17)$ & $19.6(6.81)$ & $* *$ \\
\hline
\end{tabular}

$* p<.05,{ }^{* *} p<.01 .^{\mathrm{a}}$ Indicates standardized scores; other scores presented as raw scores

The values of RT word and non-word reading subtests represent the number of correct responses participants made in 45 seconds.

The values of Acc word and non-word reading subtests represent the number of correct responses participants made. 


\section{Appendix}

Table A1 - Bisection bias for every word separately for the English group

\begin{tabular}{|c|c|c|c|c|c|c|c|c|}
\hline & \multicolumn{2}{|c|}{$\begin{array}{l}\text { High frequency } \\
\text { long word }\end{array}$} & \multicolumn{2}{|c|}{$\begin{array}{l}\text { High frequency } \\
\text { short words }\end{array}$} & \multicolumn{2}{|c|}{$\begin{array}{l}\text { Low frequency } \\
\text { long words }\end{array}$} & \multicolumn{2}{|c|}{$\begin{array}{c}\text { Low frequency } \\
\text { short words }\end{array}$} \\
\hline & Word & Bias & Word & Bias & Word & Bias & Word & Bias \\
\hline 1 & anybody & -4.178 & answer & -4 & alphabet & -1.555 & agency & -0.966 \\
\hline 2 & country & -4.793 & apple & -4.15 & arbiter & -1.444 & angel & -1.133 \\
\hline 3 & evening & -0.407 & circle & -0.75 & assemble & -5.538 & chink & 3.678 \\
\hline 4 & lecture & 2.233 & driver & -3.23 & beehive & -3.214 & clove & 0.793 \\
\hline 5 & meeting & 0 & earth & 1.425 & exterior & -2.037 & crane & -0.103 \\
\hline 6 & mixture & -2.034 & heart & -1.871 & haddock & -2.230 & haste & -0.5 \\
\hline 7 & picture & 1.666 & heat & 1.425 & harbour & -6.535 & hunter & -1.034 \\
\hline 8 & problem & -2.172 & height & -3.594 & harness & -1.92 & manor & -1.466 \\
\hline 9 & purpose & -6.076 & metal & -0.775 & harvest & -0.833 & marble & -1.655 \\
\hline 10 & respect & -2.758 & mirror & -2.333 & maternity & -4.517 & minnow & -1.033 \\
\hline 11 & society & -2.6 & money & -3.410 & maturity & -1.357 & regin & 2.133 \\
\hline 12 & square & -0.965 & mother & -3 & pampas & -0.766 & scorn & -0.034 \\
\hline 13 & student & -2.037 & music & -0.875 & profiteer & -2.642 & spurt & 1.566 \\
\hline 14 & weather & -0.928 & penny & -0.108 & shutter & -3.172 & tailor & -3.3 \\
\hline 15 & writing & -0.037 & thumb & 3.675 & soldier & -2.307 & violet & 2.206 \\
\hline
\end{tabular}


Table A2 - Bisection bias for every word separately for the Hebrew group

\begin{tabular}{|c|c|c|c|c|c|c|c|c|}
\hline & \multicolumn{2}{|c|}{$\begin{array}{l}\text { High frequency } \\
\text { long word }\end{array}$} & \multicolumn{2}{|c|}{$\begin{array}{l}\text { High frequency } \\
\text { short words }\end{array}$} & \multicolumn{2}{|c|}{$\begin{array}{l}\text { Low frequency } \\
\text { long words }\end{array}$} & \multicolumn{2}{|c|}{$\begin{array}{l}\text { Low frequency } \\
\text { short words }\end{array}$} \\
\hline & Word & Bias & Word & Bias & Word & Bias & Word & Bias \\
\hline 1 & אוזניים & 1.392 & דמיוני & -2.566 & אלומיניום & -3.928 & אוניה & -0.666 \\
\hline 2 & אוטובוס & 1.428 & הרגשה & 1.666 & אקורדיון & 0.481 & הרפתקה & -0.433 \\
\hline 3 & אופניים & 0.366 & התבייש & -3.714 & אקסיומה & -0.428 & חיסור & -1.034 \\
\hline 4 & אשכולית & -2.75 & חולצה & 3 & ביכורים & 1.333 & חלמון & 0.366 \\
\hline 5 & גולגולת & 1.689 & יוגורט & 3.357 & התנגדות & -2.571 & כומתה & -0.965 \\
\hline 6 & גרעינים & 0.222 & מדינה & -2.133 & התפטרות & -2.615 & מותרות & -0.758 \\
\hline 7 & טלביזיה & -3.448 & ממשלה & -1.379 & התרשמות & -2.814 & מלכודת & -3.966 \\
\hline 8 & לחמנייה & -4.037 & מנגינה & 1.241 & חנוכייה & 0.896 & ממחטה & 0.62 \\
\hline 9 & מכנסיים & 0.25 & מקולקל & -2.379 & מאוזניים & 1.370 & ציונות & -1.137 \\
\hline 10 & מספריים & -0.931 & משפחה & -2.535 & מצילתיים & -2.1 & קובייה & -3.433 \\
\hline 11 & משקפיים & 2.2 & עדינות & -4.678 & סוכרייה & -0.566 & רחמים & 1 \\
\hline 12 & נקניקיה & 2.555 & עיתון & -5.6 & פירמידה & -0.92 & שיכון & -4.275 \\
\hline 13 & קילומטר & 0.533 & עניין & -3.793 & פרוטוקול & -1.166 & שעועית & 2.428 \\
\hline 14 & תיאטרון & -0.071 & פרסום & 0.433 & שערוריה & -2.655 & שרוול & -5.833 \\
\hline 15 & תרנגולת & -0.214 & תשובה & -1.285 & אקליפטוס & -3.928 & תרנגול & -3 \\
\hline
\end{tabular}


Table A3 - Bisection bias for every word separately for the Hebrew DD group

\begin{tabular}{|c|c|c|c|c|c|c|c|c|}
\hline & \multicolumn{2}{|c|}{$\begin{array}{l}\text { High frequency } \\
\text { long word }\end{array}$} & \multicolumn{2}{|c|}{$\begin{array}{l}\text { High frequency } \\
\text { short words }\end{array}$} & \multicolumn{2}{|c|}{$\begin{array}{l}\text { Low frequency } \\
\text { long words }\end{array}$} & \multicolumn{2}{|c|}{$\begin{array}{l}\text { Low frequency } \\
\text { short words }\end{array}$} \\
\hline & Word & Bias & Word & Bias & Word & Bias & Word & Bias \\
\hline 1 & אוזניים & 1.533 & דמיוני & -4.063 & אלומיניום & -4.219 & אוניה & 1.813 \\
\hline 2 & אוטובוס & -1.233 & הרגשה & 1.844 & אקורדיון & -0.935 & הרפתקה & -2.906 \\
\hline 3 & אופניים & -3.875 & התבייש & -1.733 & אקסיומה & -7.103 & חיסור & -1.710 \\
\hline 4 & אשכולית & -3.031 & חולצה & -0.714 & ביכורים & -0.906 & חלמון & -3.813 \\
\hline 5 & גולגולת & -1.781 & יוגורט & 1.355 & התנגדות & -4.677 & כומתה & -2.400 \\
\hline 6 & גרעינים & -0.903 & מדינה & -3.774 & התפטרות & -5.531 & מותרות & -4.742 \\
\hline 7 & טלביזיה & -5.062 & ממשלה & -1.000 & התרשמות & -5.033 & מלכודת & -3.875 \\
\hline 8 & לחמנייה & -8.322 & מנגינה & -3.219 & חנוכייה & 0.400 & ממחטה & -3.300 \\
\hline 9 & מכנסיים & -1.258 & מקולקל & -0.300 & מאוזניים & -0.063 & ציונות & -2.469 \\
\hline 10 & מספריים & -2.967 & משפחה & -3.586 & מצילתיים & -1.097 & קובייה & -4.250 \\
\hline 11 & משקפיים & -3.233 & עדינות & -1.875 & סוכרייה & -3.313 & רחמים & 2.097 \\
\hline 12 & נקניקיה & -0.468 & עיתון & -4.563 & פירמידה & -1.467 & שיכון & -7.167 \\
\hline 13 & קילומטר & -0.937 & עניין & -4.875 & פרוטוקול & -0.355 & שעועית & -1.516 \\
\hline 14 & תיאטרון & -1.387 & פרסום & 0.313 & שערוריה & -4.625 & שרוול & -2.645 \\
\hline 15 & תרנגולת & -4.566 & תשובה & -3.484 & אקליפטוo & -1.987 & תרנגול & -2.323 \\
\hline
\end{tabular}

